\title{
シャイネスと自己呈示規範内在化における性差およびその関係性に関する研究
}

\author{
○原田卓也 ${ }^{1} \cdot$ 岩淵千明 ${ }^{2}$ \\ ( ${ }^{1}$ 医療法人永和会 $\cdot{ }^{2}$ 川崎医療福祉大学医療福祉学部臨床心理学科 $)$ \\ キーワード : シャイネス, 自己呈示規範内在化, 自己呈示欲求
}

\section{Study on Relationship between Shyness and Self-presentational norms}

Takuya HARADA ${ }^{1}$, Chiaki IWABUCHI ${ }^{2, \#}$

$\left({ }^{1}\right.$ Medical Copolation Eiwakai ${ }^{2}$ Kawasaki University of Medical Welfare Clinical Psychology, Faculty of Health and Welfare) Key Words: Shyness, Self-presentational norms

\section{目 的}

日本人の若者は欧米人より「シャイネス」経験が高いとさ れている。後藤（2004）によれば，日本人の $90 \%$ 以上が自分 を「シャイ」だと感じた経験があり，75\%がシャイな自分は 問題と考えているとZimbardo（1977）が報告している。

Zimbardo,P.G, Pilkonis,P.A., \& Norwood,R.M.（1974）は, シャイネスは人を謙虚に見せるなどの一定の長所はあるが基 本的には克服すべきものであると問題点を指摘している。一 方で，藤井・澤海・相川（2015）は，潜在的なシャイネスに は主観的幸福感と関係性があることが認められ, 容易に不適 応的だと結論づけることはできないことを指摘している。こ のようなシャイネスを理解するためには, 自己呈示の視点が 有用であるとしている。

自己呈示には, 社会的な規範も存在し, 自分の有能さを積 極的に売り込む場合と謙虚に振舞う場合の 2 つに大別されて いる（久保，1998）。さらに，自己呈示の社会的な規範には文 化による違いも存在し, 日本文化は「恥の文化」ともいわれ る。吉田・浦（2003）は, 日本文化には自己卑下呈示を望ま しいとする文化的な自己呈示規範が存在するとしている。

これらのことから本研究は, シャイネスと自己呈示規範の 内在化との関係性に注目して検討していくことを目的とする。

\section{方 法}

調査協力者 $\mathrm{K}$ 大学の在学生 286 名（男性 106 名, 女性 186 名）を分析対象とした。

調查方法 大学の講義時間中に, 質問紙の配布と回収をおこ なった。

調査時期 2016 年 7 月から 8 月にかけて実施した。

質問紙構成 1. シャイネス:菅原 (1998) が作成したシャイ ネス尺度を用いた。この尺度は, 対人不安傾向（9項目）, 対 人消極傾向 (8 項目) の 2 因子で合計 17 項目から構成されて いる。「全く当てはまらない」 1 点から「よく当てはまる」5 点の 5 件法である。本研究では, この尺度の合計点をシャイ ネス得点とした。2. 自己呈示規範内在化: 吉田・浦 (2003) が作成した自己呈示規範内在化尺度を用いた。この尺度は, 自己卑下呈示内在化 (11 項目), 自己高揚呈示内在化 (11 項 目）の 2 因子で合計 22 項目で構成されている。「全く望まし くない」 1 点から「非常に望ましい」 5 点の 5 件法である。

\section{結 果}

尺度の信頼性 各尺度についてそれぞれが 2 因子が存在す ることを確認するために, 確証的因子分析（主因子法, プロ マックス回転）をおこなった。その結果，全ての尺度におい て2つの因子を確認できた。次に, 各項目の回答分布に極端 な偏りがないことを確認した後, Cronbach の $\alpha$ 係数を算出し た。その結果, $\alpha$ 係数の若干低い項目がみられたが, 解釈上 の留意が必要であることを確認し, 以下の分析をおこなった。
シャイネスと自己呈示規範内在化における性差 $\mathrm{t}$ 検定の 結果, シャイネス尺度 $(t(284)=-2.86, p<0.1)$ と対人不安傾 向 $(t(284)=-3.32, p<.001)$ は女性の方が男性よりも高いと いう結果となった。自己呈示規範の内在化には有意な差異は 認められなかった。

表 1 各尺度と各因子の信頼性, 平均値, 標準偏差

\begin{tabular}{lccc}
\hline \multicolumn{1}{c}{ 尺度 } & \multicolumn{3}{c}{ 全体 $(\mathrm{N}=286)$} \\
\hline 1.シャイネス尺度 & $\mathrm{a}$ & $\mathrm{M}$ & $\mathrm{SD}$ \\
対人不安傾向 & .85 & 59.44 & 10.10 \\
対人消極傾向 & .84 & 34.58 & 6.38 \\
2.自己呈示規範内在化尺度 & .79 & 24.85 & 5.72 \\
自己卑下呈示内在化 & .54 & 70.47 & 6.51 \\
自己高揚呈示内在化 & .64 & 32.14 & 5.00 \\
\hline
\end{tabular}

変数間の相関関係 先行研究では, シャイネスと性差につ いての見解が一致していない。このことから，男女別に相関 関係数（ピアソンの積率相関係数）を算出した（表 2 ; 左下 が女性, 右上が男性)。その結果, 自己卑下呈示内在化は, 男 性のみでシャイネス得点と対人不安傾向と有意な正の相関が 認められた。自己高揚呈示内在化は, 女性のみで対人消極傾 向と自己卑下呈示内在化と有意な負の相関が認められた。そ して, 男女ともに対人不安傾向と自己高揚呈示内在化の間に 正の相関，対人消極傾向の間に負の相関が認められた。

表 2 変数間における各相関係数（上：男，下：女）

\begin{tabular}{|c|c|c|c|c|c|c|c|}
\hline 指標 & (1) & (2) & (3) & $(4)$ & & (5) & (6) \\
\hline (1) シヤイネス尺度全体 & & $.83^{* *}$ & $.80^{* *}$ & .32 & ** & .37 ** & .08 \\
\hline (2) 対人不安傾向 & $.86^{* *}$ & & $.33^{* *}$ & .39 & ** & .28 ** & $.26^{* *}$ \\
\hline (3) 対人消極傾向 & $.83^{* *}$ & $.43^{* *}$ & & .13 & & .32 ** & $\because .14$ \\
\hline (4) 自己呈示規範内在化尺度 & .08 & $.16^{*}$ & -.03 & & & $.68^{* *}$ & $.71^{* *}$ \\
\hline (5) 自己卑下呈示内在化 & .10 & .02 & $.15^{*}$ & .50 & $* *$ & & -.04 \\
\hline (6) 自己高揚呈示内在化 & .00 & $.16 *$ & -.17 * & .64 & $* *$ &. .35 ** & \\
\hline
\end{tabular}

\section{考 察}

シャイな人物でも，対人不安傾向が高い者の場合は自己高 揚呈示を望ましいと考え, 対人消極傾向の高い者の場合は自 己卑下呈示を望ましいと考えることが明らかになった。

女性の場合であれば，対人消極傾向が強い人は自己卑下呈 示を望ましいとはしていなかった。このことは, 対人関係に 対して関心のない者は, 顔色を窥ってまで他者から評価を得 ようとする動機が薄いことが考えられる。

男性の場合は, 対人不安傾向が強い人は自己卑下呈示を望 ましいとしていた。つまり, 男性は集団の中で適応していく 中で生まれる周囲から拒絶されることへの不安に, 自己を卑 下して呈示することで対処しようとしていると考えられる。 